\title{
1 Ecosystem Services in Global Sustainability Policies
}

3 Ilse R. Geijzendorffer ${ }^{1,2 *}$, Emmanuelle Cohen-Shacham ${ }^{3}$, Anna F. Cord ${ }^{4}$, Wolfgang Cramer ${ }^{1}$, Carlos

4 Guerra $^{5,6}$, Berta Martín-López ${ }^{7}$

5

6 Affiliations:

$7{ }^{1}$ Institut Méditerranéen de Biodiversité et d'Ecologie marine et continentale (IMBE), Aix Marseille

8 Université, CNRS, IRD, Avignon Université, Aix-en-Provence, France

$9{ }^{2}$ Tour du Valat, Research Institute for the conservation of Mediterranean Wetlands, Le Sambuc, 13200

10 Arles, France

$11{ }^{3}$ Department of Zoology, Life Sciences Faculty, Tel-Aviv University, 69978 Tel-Aviv, Israel ${ }^{4}$ Department of

12 Computational Landscape Ecology, Helmholtz Centre for Environmental Research - UFZ, Permoserstraße

1315,04318 , Leipzig, Germany

$14{ }^{5}$ German Centre for Integrative Biodiversity Research (iDiv), Halle-Jena-Leipzig, Deutscher Platz 5e,

15 04103, Leipzig, Germany

$16{ }^{6}$ Institute of Biology, Martin Luther University Halle-Wittenberg, Am Kirchtor 1, 06108, Halle (Saale),

17 Germany

$18{ }^{7}$ Leuphana University, Faculty of Sustainability, Institute of Ethics and Transdisciplinary Sustainability

19 Research, Lüneburg, Scharnhorststr. 1, 21335 Lüneburg, Germany

$20 *$ Corresponding author:

21 E-mail:geijzendorffer@tourduvalat.org;

22 Tel.: 0033 652926228;

23 Permanent address: Tour du Valat, Research Institute for the conservation of Mediterranean Wetlands, 24 Le Sambuc, 13200 Arles, France

25

Paper content (total words 7282): Abstract (273) + Main body (total words $4424=$ Introduction (663) + M\&M (1104) + Results and Discussion (2761) + Conclusion (192)) + Acknowledgements (95) + References

28 (1796). The manuscript contains 4 Figures (296 words), 3 Tables (668 words), 55 References and an 29 Online appendix. 


\section{Abstract}

32 Global sustainability policies, such as the Sustainable Development Goals (SDGs) or the Aichi Targets, aim

33 to ensure sustainable development, including improved human well-being and the conservation of nature. Although not yet explicitly used to evaluate the progress towards sustainable development, the ecosystem service concept implies a direct link between biodiversity and human well-being. This study explores how and which ecosystem services are currently considered in the SDGs and the Aichi Targets. We also identify which information might be already available for monitoring the progress towards their goals by reviewing national ecosystem assessments. This allows the identification of the main knowledge gaps for monitoring progress towards these global sustainability targets.

There is a wealth of information on all major ecosystem services categories which is directly relevant for the Aichi Targets and the SDGs. The top 25\% most cited ecosystem services across both policy documents are: Natural heritage and diversity, Capture fisheries, Aquaculture, Water purification, Crops, Cultural heritage \& diversity and Livestock. Most monitoring information recommended for the global sustainability goals, as well as in the information available from national assessments, is biased towards supply related aspects of ecosystem services flows. In contrast, there is much less information on social behaviour, use, demand and governance measures. Indicators are rarely available for all aspects of a specific ecosystem service.

The national statistical bureaus currently in charge of providing observations for reporting on SDGs, could be well placed to address this bias, by integrating ecological observations with socio-economic statistics into socio-ecological indicators for ecosystem services flows. IPBES can potentially address the gaps identified in this paper by improving coverage of the different dimensions of ecosystem services 52 flows.

Keywords: Aichi Targets, human well-being, indicators, monitoring, reporting, Sustainable Development 55 Goals.

\section{Highlights}

- All ecosystem services categories are relevant for the Aichi Targets and the SDGs

- There is an information bias towards the supply side of ecosystem services

- Information on social behaviour and governance is lacking for ecosystem services flows

- Trade-offs caused by unsustainable development will likely remain undetected

- IPBES and national statistical bureaus offer an opportunity to improve ecosystem services assessments 


\section{Introduction}

Multiple international policy objectives aim to ensure human well-being and the sustainability of the planet, whether via sustainable development of society or via biodiversity conservation, e.g. the Sustainable Development Goals (SDGs) and the Conventional of Biological Diversity (CBD) Aichi Targets. To evaluate progress made towards these objectives and to obtain information on the efficiency of implemented measures, effective monitoring schemes and trend assessments are required (Hicks et al. 2016). Whereas the CBD has been reporting on progress towards objectives in Global Outlooks since $2001^{1}$, a first list of indicators has recently been launched.

There is broad consensus that pathways to sustainability require a secure supply of those ecosystem services that contribute to human well-being (Fig. 1; Griggs et al., 2013; Wu, 2013). The ecosystem service concept is an important integrated framework in sustainability science (Liu et al., 2015), even if the term ecosystem services is not often explicitly mentioned in policy objectives. Nevertheless, a number of specific ecosystem services are mentioned in documents relating to the different objectives stated in the SDGs and Aichi Targets. For example, there is an explicit mentioning of regulation of natural hazards in SDG 13 and of carbon sequestration in Aichi Target 15. Especially for the poorest people, who most directly depend on access to ecosystems and their services (Daw et al., 2011; Sunderlin et al., 2005), information on ecosystem services state and trends should be highly relevant (Wood and DeClerck, 2015).

ECOSYSTEM SERVICES

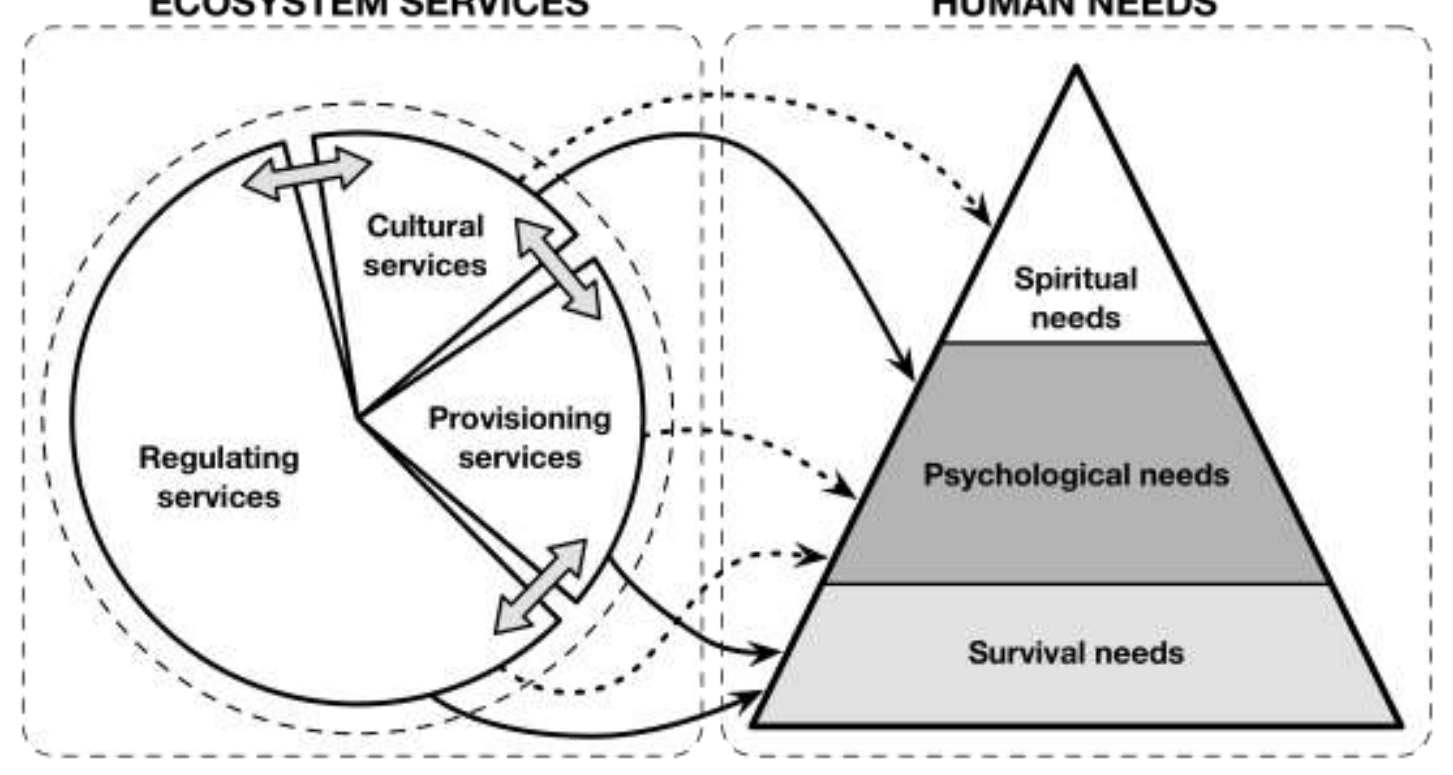

Figure 1. Contribution of ecosystem services to human well-being, with direct contributions being

\footnotetext{
${ }^{1}$ (https://www.cbd.int/gbo/) last consulted on the $22^{\text {nd }}$ of April 2017
} 
Trends in biodiversity, ecosystem services and their impact on human well-being as well as sustainability must be studied using an integrated approach (Bennett et al., 2015; Liu et al., 2015). The SDG ambitions could potentially offer key elements for this integration. Most assessments use a pragmatic approach to select indicators for ecosystem services, often only focusing on those indicators and ecosystem services, for which data are readily available. Although this helps to advance the knowledge on ecosystem services on many aspects, it may not cover the knowledge required to monitor progress towards sustainability (Hicks et al., 2016). Regions characterized by high vulnerability of ecosystem services supply and human well-being, such as the Mediterranean Basin (Schröter et al., 2005), require information on the trends in on all aspects ecosystem services flows including the impact of governance interventions and pressures on social-ecological systems.

Considerable progress has been made in developing integrative frameworks and definitions for ecosystem services and the quantification of indicators (e.g. Kandziora et al., 2013; Maes et al., 2016), but it is unclear to which extent the current state of the art in ecosystem services assessments is able to provide the information required for monitoring the SDGs and the Aichi Targets. Since the publication of the Millennium Ecosystem Assessment in 2005, multiple national ecosystem services assessments have been undertaken, such as the United Kingdom National Ecosystem Assessment (UK National Ecosystem Assessment, 2011), the Spanish NEA (Santos-Martín et al., 2013) or the New Zealand assessment (Dymond, 2013). Furthermore, in the context of the Intergovernmental Platform on Biodiversity and Ecosystem Services (IPBES), regional and global assessments are planned for 2018 and 2019, respectively. The ecosystem services indicators used in these national, regional and global assessments could also provide relevant information for monitoring the progress towards these global sustainability objectives.

The main goal of the present study is to explore to what extent the ecosystem services concept has been incorporated in global sustainability policies, particularly the SDGs and the Aichi Targets. For this objective, we i) assessed the information on ecosystem services currently recommended to monitor the progress on both policy documents and ii) identified which information on ecosystem services can already be provided on the basis of the indicators reported in national ecosystem assessments. Based on these two outputs, we iii) identified knowledge gaps regarding ecosystem services for monitoring the progress on global policy objectives for sustainability.

\section{Material and methods}

Numerous frameworks exist to describe ecosystem services (e.g., Kandziora et al., 2013; Maes et al., 2016), but there is general agreement that a combination of biophysical, ecological and societal components is required to estimate the flow of actual benefits arriving to the beneficiary. In line with the ongoing development of an Essential Ecosystem Services Variable Framework in the scope of the Global Earth Observation Biodiversity Observation Network (GEO BON), we used a framework that distinguishes variables of ecosystem services flows (Tab. 1): the ecological potential for ecosystem services supply (Potential supply), and the societal co-production (Supply), Use of the service, Demand for the service as well as Interests and governance measures for the service (Tab. 1, adapted from Geijzendorffer et al., 2015). We hereafter refer to these variables with capitals to increase the readability of the text. Using this framework, we i) identified and ranked the frequency at which specific ecosystem services are 
mentioned, within and across the selected policy documents (CBD, 2013; United Nations, 2015a); ii) reviewed indicators currently used for reporting on the Aichi Targets (Global Outlook) and iii) reviewed the 277 indicators currently being used in national ecosystem assessments, to identify any existing information gaps.

Only monitoring data that feed all the variables of this framework allows detecting trends and interpreting changes in ecosystem services flow. One example relevant for the SDGs is a food deficit indicator (e.g. insufficient calories intake per capita). An increase in calorie intake in a specific country would indicate the need for additional interventions. However, depending on the cause of this increased deficit, some interventions are more likely to be effective than others. For example, the food deficit could be caused by a change in demand (e.g. increased population numbers), in the service supply (e.g. agricultural land abandonment), or in the ecological potential to supply services (e.g. degradation of soils).

We structured our analysis of indicators by distinguishing between indirect and direct indicators (Tab. 1). While direct indicators assess an aspect of an ecosystem service flow (e.g. tons of wheat produced), indirect indicators provide proxies or only partial information (e.g. hectares of wheat fields under organic management) necessary to compute the respective indicator. Our review does not judge the appropriateness or robustness of the respective indicator (as proposed by Hák et al., 2016), nor did we aim to assess whether the underlying data source was reliable or could provide repeated measures of indicators over time. We only looked at the type of information that was described for each of the ecosystem services mentioned in the policy objectives and the type of indicators proposed for reporting on these policies.

The data for reporting on the SDGs is currently provided by national statistical bureaus and we therefore wanted to identify which ecosystem services indicators might be available at this level. To get a first impression, we reviewed the indicators used in 9 national ecosystem assessments and the European ecosystem assessment.

A network analysis was used to determine the associations between i) ecosystem services within the SDGs and the CBD Aichi Targets, ii) the variables of ecosystem services flows and proposed indicators for both policies and iii) the categories of ecosystem services and the components of the ecosystem service flow, in the indicators used in national and the European ecosystem assessments. The network analysis was performed using Gephi (Bastian et al., 2009) and their visualization was subsequently produced using NodeXL (https://nodexl.codeplex.com/, last consulted January $13^{\text {th }} 2017$ ). 
Table 1: Evaluation framework for the indicators on ecosystem service flows (adapted from Geijzendorffer et al., 2015). While direct indicators can be used to immediately assess the needed information, indirect indicators provide proxies or only partial information necessary to compute the respective indicator.

\begin{tabular}{|c|c|c|c|c|}
\hline $\begin{array}{l}\text { Information } \\
\text { component }\end{array}$ & Definition & Related terms used in other papers & $\begin{array}{l}\text { Examples of direct } \\
\text { indicators }\end{array}$ & $\begin{array}{l}\text { Examples of indirect } \\
\text { indicators }\end{array}$ \\
\hline $\begin{array}{l}\text { Potential } \\
\text { Supply }\end{array}$ & $\begin{array}{l}\text { Estimated supply of ecosystem } \\
\text { services based on ecological and } \\
\text { geophysical characteristics of } \\
\text { ecosystems, taking into account } \\
\text { the ecosystem's integrity, under } \\
\text { the influence of external drivers } \\
\text { (e.g., climate change or } \\
\text { pollution). }\end{array}$ & $\begin{array}{l}\text { Ecosystem functions (de Groot et } \\
\text { al., 2002); ecosystem properties } \\
\text { that support ecosystem functions } \\
\text { (van Oudenhoven et al., 2012) }\end{array}$ & $\begin{array}{l}\text { Modelled estimates of } \\
\text { harvestable biomass under } \\
\text { natural conditions; potential } \\
\text { pressures that an ecosystem } \\
\text { can absorb; landscape } \\
\text { aesthetic quality. }\end{array}$ & $\begin{array}{l}\text { Qualitative estimates of } \\
\text { land cover type } \\
\text { contributions to biomass } \\
\text { growth; species traits (e.g. } \\
\text { root growth patterns); } \\
\text { landscape heterogeneity } \\
\text { of land cover types. }\end{array}$ \\
\hline $\begin{array}{l}\text { Managed } \\
\text { Supply }\end{array}$ & $\begin{array}{l}\text { Type and quantity of services } \\
\text { supplied by the combination of } \\
\text { the Potential supply and the } \\
\text { impact of interventions (e.g., } \\
\text { management) by people in a } \\
\text { particular area and over a } \\
\text { specific time period. }\end{array}$ & $\begin{array}{l}\text { Capacity (Schröter et al., 2005), } \\
\text { supply (Crossman et al., 2013), } \\
\text { service capacity (Villamagna et al., } \\
\text { 2013); supply capacity of an area } \\
\text { (Burkhard et al., 2012); actual } \\
\text { ecosystem service provision (Guerra } \\
\text { et al., 2014); ecosystem functions } \\
\text { under the impact of "land } \\
\text { management" (van Oudenhoven et } \\
\text { al., 2012); Service Providing Unit- } \\
\text { Ecosystem Service Provider } \\
\text { Continuum (Harrington et al., 2010). }\end{array}$ & $\begin{array}{l}\text { Harvested biomass; } \\
\text { potential pressures that a } \\
\text { managed landscape can } \\
\text { absorb; extent of landscape } \\
\text { made accessible for } \\
\text { recreation. }\end{array}$ & $\begin{array}{l}\text { Modelled estimates of } \\
\text { harvestable biomass under } \\
\text { managed conditions; soil } \\
\text { cover vegetation } \\
\text { management; financial } \\
\text { investments in } \\
\text { infrastructure. }\end{array}$ \\
\hline Use & $\begin{array}{l}\text { Quantity and type of services } \\
\text { used by society. }\end{array}$ & $\begin{array}{l}\text { Flow (Schröter, 2005; Schröter et } \\
\text { al., 2014); service flow (Villamagna } \\
\text { et al., 2013); "demand" (match and } \\
\text { demand aggregated into one term) } \\
\text { (Burkhard et al., 2012; Crossman et } \\
\text { al., 2013). }\end{array}$ & $\begin{array}{l}\text { Biomass sold or otherwise } \\
\text { used; amount of soil erosion } \\
\text { avoided while exposed to } \\
\text { eroding pressures; number } \\
\text { of people actually visiting a } \\
\text { landscape. }\end{array}$ & $\begin{array}{l}\text { Estimations of biomass use } \\
\text { for energy by households; } \\
\text { reduction of soil erosion } \\
\text { damage; distance } \\
\text { estimates from nearby } \\
\text { urban areas. }\end{array}$ \\
\hline
\end{tabular}




\begin{tabular}{|l|l|l|l|l|} 
Demand & $\begin{array}{l}\text { Expression of demands by } \\
\text { people in terms of actual } \\
\text { allocation of scarce resources } \\
\text { (e.g. money or travel time) to } \\
\text { fulfil their demand for services, } \\
\text { in a particular area and over a } \\
\text { specific time period. }\end{array}$ & $\begin{array}{l}\text { Stakeholder prioritisation of } \\
\text { ecosystem services (Martín-López } \\
\text { et al., 2014), service demand } \\
\text { (Villamagna et al., 2013), demand } \\
\text { (Burkhard et al., 2012). }\end{array}$ & $\begin{array}{l}\text { Prices that people are willing } \\
\text { to pay for biomass; amount } \\
\text { of capital directly threatened } \\
\text { by soil erosion; time } \\
\text { investment, travel distances } \\
\text { and prices people are willing } \\
\text { to pay to visit a landscape. }\end{array}$ & $\begin{array}{l}\text { Computation of average } \\
\text { household needs; } \\
\text { remaining soil erosion } \\
\text { rates; survey results on } \\
\text { landscape appreciation. }\end{array}$ \\
\hline Interests & $\begin{array}{l}\text { An expression of people's } \\
\text { interests for certain services, in } \\
\text { a particular area and over a } \\
\text { specific time period. These tend } \\
\text { to be longer wish-lists of } \\
\text { services without prioritisation. }\end{array}$ & $\begin{array}{l}\text { Identification of those important } \\
\text { ecosystem services for } \\
\text { stakeholders' well-being (Martín- } \\
\text { López et al., 2014); beneficiaries } \\
\text { with assumed demands (Bastian et } \\
\text { al., 2013). }\end{array}$ & $\begin{array}{l}\text { Subsidies for bio-energy; } \\
\text { endorsement of guidelines } \\
\text { for best practices for soil } \\
\text { management; publicity for } \\
\text { outdoor recreation. }\end{array}$ & $\begin{array}{l}\text { Number of people } \\
\text { interested in green energy; } \\
\text { number of farmers aware } \\
\text { of soil erosion; average } \\
\text { distance of inhabitants to } \\
\text { green areas. }\end{array}$ \\
\hline
\end{tabular}




\subsection{Identification of ecosystem services in the SDGs and Aichi Targets}

Two international policy documents were selected for review: the SDGs (United Nations, 2015a) and the CBD Aichi Targets (CBD, 2013). Both documents have global coverage and contain objectives on sustainable development, related to maintaining or improving human well-being and nature. The classification of ecosystem services used in this paper is based on Kandziora et al. (2013), which matched best with the terminology of policy documents and the national assessments.

For each policy document, we determined the absolute and relative frequency at which an ecosystem service was mentioned. This frequency was also used to produce a relative ranking of ecosystem services, within and across these policy documents. Although the SDGs and the Aichi Targets include several statements on specific ecosystem services (e.g. food production, protection from risks), the term "ecosystem services" is not often mentioned. In the SDGs, for instance, ecosystem services explicitly occur only once (Goal 15.1). In contrast, "sustainable development or management" and "sustainable use of natural resources" are mentioned several times, although not further specified. While the latter could be interpreted to mean that the use of nature for provisioning purposes should not negatively affect regulating services, we preferred to remain cautious and not make this assumption, when reviewing the policy documents. We are therefore certain that we underestimate the importance of knowledge on ecosystem services regarding the different policy objectives.

\subsection{Proposed ecosystem services indicators for the SDGs and Aichi Targets}

In addition to the ecosystem services directly mentioned in the policy objectives, we also reviewed the type of information on ecosystem services proposed to monitor the progress towards the policy objectives. To this end, we used the 2015 UN report (United Nations, 2015b) for the SDGs. For the Aichi Targets, we focused on the recently proposed (but still under development) indicator list (CBD, 2015) and on the indicators recently used in the Global Biodiversity Outlook 4 (CBD, 2014).

\subsection{Review of national ecosystem services assessments}

Although many authors propose indicators for ecosystem services (e.g. Böhnke-Hendrichs et al., 2013; Kandziora et al., 2013), not all indicators can be used for monitoring, due to lack of available data at the relevant scale or because current inventories do not provide sufficient time series for trend assessment. For the $\mathrm{CBD}$ reporting, continuous efforts are made to provide monitoring information at global level, for instance via the use of Essential Biodiversity Variables (e.g. O'Connor et al., 2015). Reporting for the SDGs, however, will heavily rely on the capacity of national statistical bureaus to provide the required data (ICSU, ISSC, 2015).

To estimate the type of ecosystem services indicators that might be available at national level, we selected national ecosystem assessment reports, which were openly available and written in one of the seven languages mastered by the co-authors (i.e. English, Spanish, Portuguese, Hebrew, French, German and Dutch). Nine assessments fulfilled these criteria (see Tab. 2). We complemented them with the European report (Maes et al., 2015), which is considered to be a baseline reference for upcoming national assessments in European member states. The selection criteria resulted in the inclusions of 
national assessments from three continents, but there is a bias towards European and developed countries.

Table 2: Ecosystem service assessments considered in the analysis

\begin{tabular}{|c|c|}
\hline Included countries & Reference \\
\hline Belgium & (Stevens, 2014) \\
\hline Europe & (Maes et al., 2015) \\
\hline Finland & $\begin{array}{l}\text { http://www.biodiversity.fi/ecosystemservice } \\
\text { s/home, last consulted January } 13^{\text {th }} 2017\end{array}$ \\
\hline New Zealand & (Dymond, 2013) \\
\hline South Africa & (Reyers et al., 2014) \\
\hline South Africa, Tanzania and Zambia & (Willemen et al., 2015) \\
\hline Spain & (Santos-Martín et al., 2013) \\
\hline United Kingdom & (UK National Ecosystem Assessment, 2011) \\
\hline
\end{tabular}

\section{Results and discussion}

\subsection{Ecosystem services mentioned in policy objectives}

The need for information on ecosystem services from all three categories (i.e. provisioning, regulating and cultural) is mentioned in both policies, and reflects earlier suggestions on the integrative nature of the policy objectives on sustainable development, especially for the SDGs (Le Blanc, 2015). Among the 17 SDGs and the 20 Aichi Targets, 12 goals and 13 targets respectively, relate to ecosystem services. Across both policy documents, all ecosystem service categories are well covered, the top $25 \%$ of the most cited ecosystem services being: Natural heritage and diversity, Capture fisheries, Aquaculture, Water purification, Crops, Livestock and Cultural heritage \& diversity (Table 3). In the SDGs, provisioning services are explicitly mentioned 29 times, regulating services 33 times and cultural services 23 times. In the Aichi Targets, provisioning services are explicitly mentioned 29 times, regulating services 21 times and cultural services 13 times.

When considering the different ecosystem service categories, SDG 2 (end hunger, achieve food security and improved nutrition, and promote sustainable agriculture) and Aichi Goal B (reduce the direct pressures on biodiversity and promote sustainable use) heavily rely on provisioning services, with the latter also relying on regulating services (Fig. 2). Cultural services are more equally demanded over a range of policy objectives, with the service Natural heritage \& diversity being the most demanded ecosystem service (see Tab. A.1).

Recent reviews of scientific ecosystem services assessments (e.g. Geijzendorffer et al., 2015; Lee and Hautenbach, 2016) demonstrate that easily measurable ecosystem services (i.e. most of the provisioning services) or ecosystem services that can be quantified through modelling (i.e. many of the regulating services) are most often studied, whereas cultural ecosystem services are much less represented, despite their importance for global sustainability policies. The reason for this knowledge gap is partly theoretical (e.g. lack of agreement on for monitoring and measuring, and partly because the assessment of cultural services in particularly requires a multi-disciplinary approach (e.g. landscape ecologists, 
231 environmental anthropologists, or environmental planners) which is difficult to achieve (Hernández-

232 Morcillo et al. 2013; Milcu et al. 2013). The development of cultural services indicators would benefit

233 from a truly interdisciplinary dialogue which should take place at both national level and international

234 level to capture cultural differences and spatial heterogeneity. The capacity building objectives of IPBES

235 could provide an important global incentive to come to a structured, mutli-disciplinary and coherent

236 concept of cultural services.

237 Table 3. Frequency at which the different ecosystem services were mentioned in both policy

238 documents. Presented ecosystem services frequency scores are for the SDGs per target $(n=126)$ and for 239 the Aichi Targets per target $(n=20)$.

\begin{tabular}{|c|c|c|}
\hline Ecosystem services & SDGs & Aichi Targets \\
\hline Provisioning services (total) & 29 & 29 \\
\hline Crops & 4 & 3 \\
\hline Energy (biomass) & 2 & 1 \\
\hline Fodder & 0 & 1 \\
\hline Livestock & 4 & 3 \\
\hline Fibre & 0 & 2 \\
\hline Timber & 0 & 3 \\
\hline Wood for fuel & 2 & 1 \\
\hline Capture fisheries & 8 & 3 \\
\hline Aquaculture & 5 & 3 \\
\hline Wild foods & 2 & 3 \\
\hline Biochemicals/medicine & 0 & 3 \\
\hline Freshwater & 2 & 3 \\
\hline Regulating services (total) & 33 & 21 \\
\hline Global climate regulation & 0 & 2 \\
\hline Local climate regulation & 3 & 1 \\
\hline Air quality regulation & 2 & 0 \\
\hline Water flow regulation & 5 & 2 \\
\hline Water purification & 5 & 3 \\
\hline Nutrient regulation & 0 & 3 \\
\hline Erosion regulation & 3 & 3 \\
\hline Natural hazard protection & 6 & 1 \\
\hline Pollination & 1 & 2 \\
\hline Pest and disease control & 2 & 2 \\
\hline Regulation of waste & 6 & 2 \\
\hline Cultural services (total) & 23 & 13 \\
\hline Recreation & 4 & 0 \\
\hline Landscape aesthetics & 0 & 0 \\
\hline Knowledge systems & 2 & 3 \\
\hline Religious and spiritual experiences & 0 & 1 \\
\hline Cultural heritage \& cultural diversity & 4 & 3 \\
\hline Natural Heritage \& natural diversity & 13 & 6 \\
\hline
\end{tabular}


243

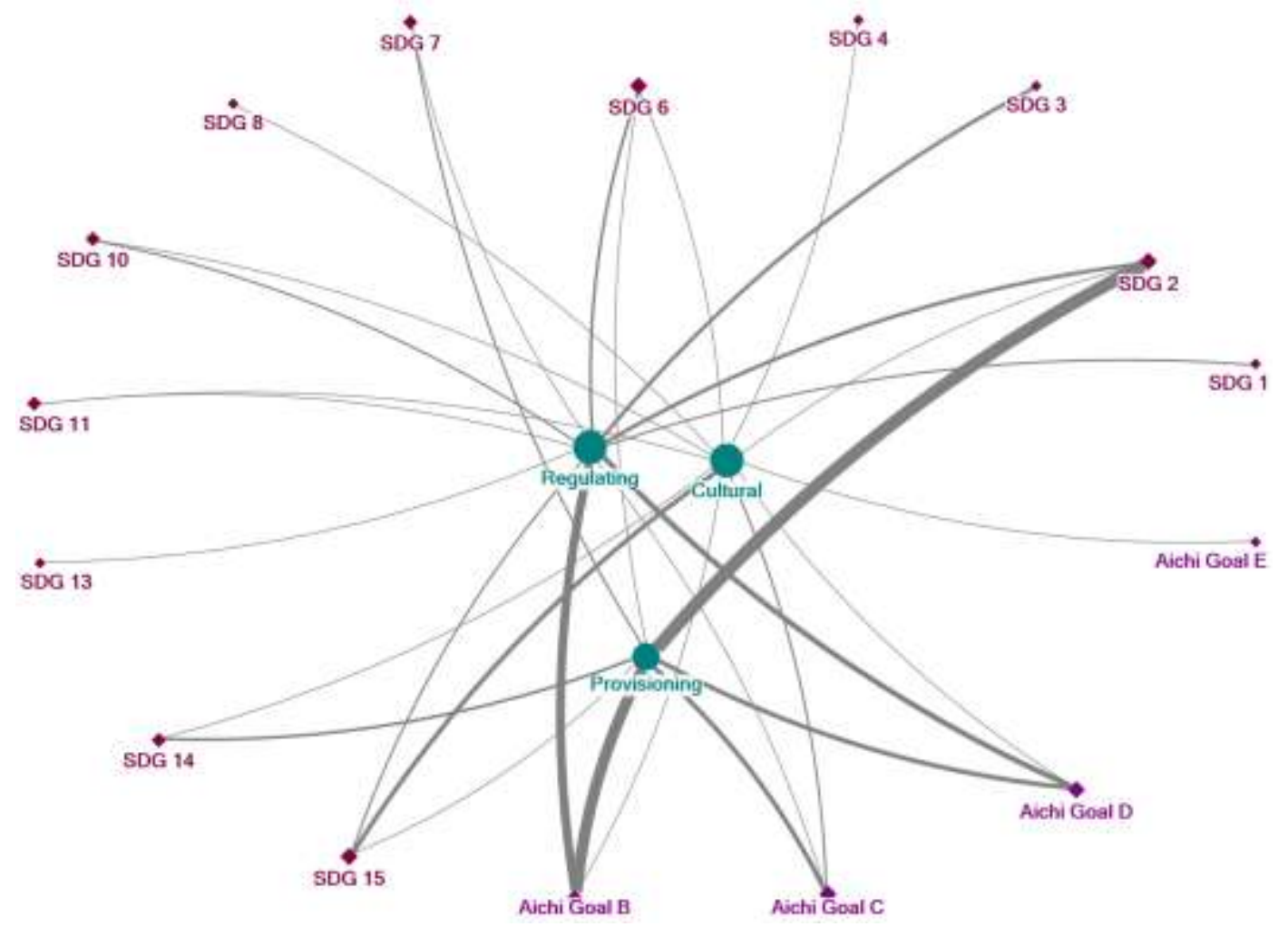

Fig 2. Relative importance of ecosystem service categories for the different policy objectives. The line width indicates the frequency at which a certain ecosystem service category was mentioned in relation to a specific goal of the SDGs or Aichi Targets (goals for which no relation to ecosystem services was found are not shown). The size of the nodes is proportional to the number of ties that a node has.

\subsection{Proposed ecosystem services indicators}

The analysis of the proposed indicators for reporting on both policy objectives $(n=119)$ demonstrated that in total 43 indicators represented information on Potential supply with the other variables being represented by indicators in the 15-24 range (Fig. 3A). This bias towards supply variables is remarkable for the Aichi Targets (Fig. 3A). Another observed pattern is that the variables Demand and Interest are more often represented by proposed indicators for the SDGs than for the Aichi Targets (i.e. demand 11 versus 5 and interest 13 versus 4 , respectively). The results therefore provide support for the claim that the SDGs aim to be an integrative policy framework (Le Blanc, 2015), at least in the sense that the proposed indicators for SDGs demonstrate a more balanced inclusion of ecological and socio-economic information.

A comparison of the number of ecosystem services that are relevant for the SDGs with the total number of indicators proposed for monitoring, however, reveals that balanced information from the indicators is unlikely to concern all ecosystem services (Figure 3). The proposed indicators never cover all five variables for a single SDG target except for one SDGs target (i.e. SDG 15: "Protect, restore and promote sustainable use of terrestrial ecosystems, sustainably manage forests, combat desertification, and halt 
and reverse land degradation and halt biodiversity loss"). Among the Aichi Targets, none of the Strategic

265 Goals was covered by indicators representing all five variables.

The frequencies at which ecosystem services are presented for the policy reports are surprisingly low (Figure 3B). In an ideal situation, each of the ecosystem services would have been covered by indicators representing the five variables (i.e. frequency value of 1). Our results demonstrate a highest frequency value of 0.4 for SDG target 13 ("Take urgent action to combat climate change and its impacts"), caused by several indicators representing only two variables (i.e. demand and interest). The SDG list of indicators is kept short on purpose to keep reporting feasible, but if the indicators and data were available through national or global platforms (e.g. IPBES, World Bank), a longer list of readily updated indicators might not be so problematic.

For the Aichi Targets, we can additionally compare between proposed indicators in the policy document and used indicators in the most recent reporting, i.e. the Global Biodiversity Outlook 4 (CBD, 2014)(Fig. $3 \mathrm{~A})$. Due to data gaps, the total number of used indicators is lower than the number of proposed indicators, but it is interesting to note what happens to the bias in the representation of the ecosystem service variables: although the indicators proposed by the policy documents showed a strong bias towards the Potential supply and the Supply variable, the indicators actually used in the reporting significantly reduce this bias. Especially for Potential supply, much less indicators are being used. actually included in the reporting (Fig. 3A).

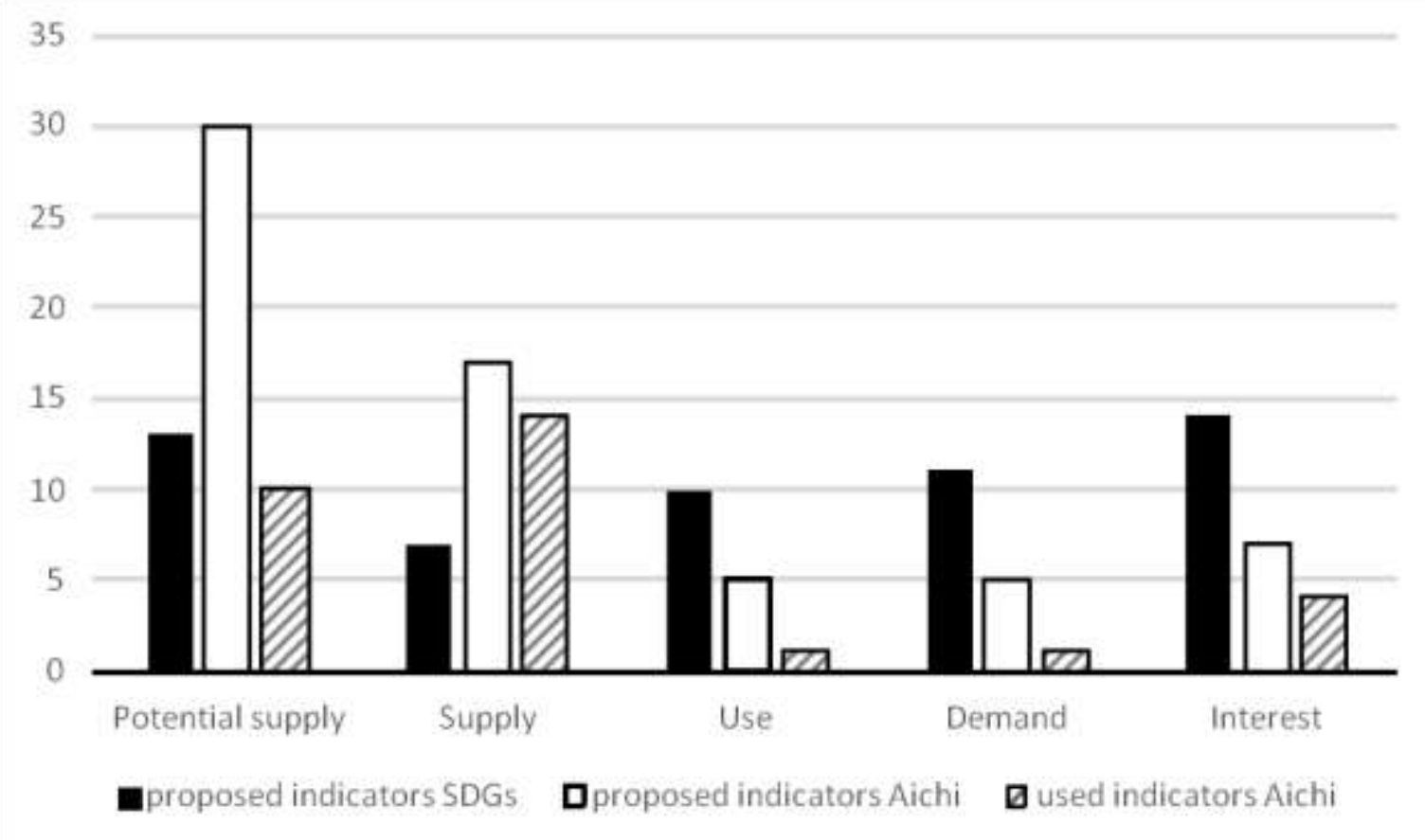




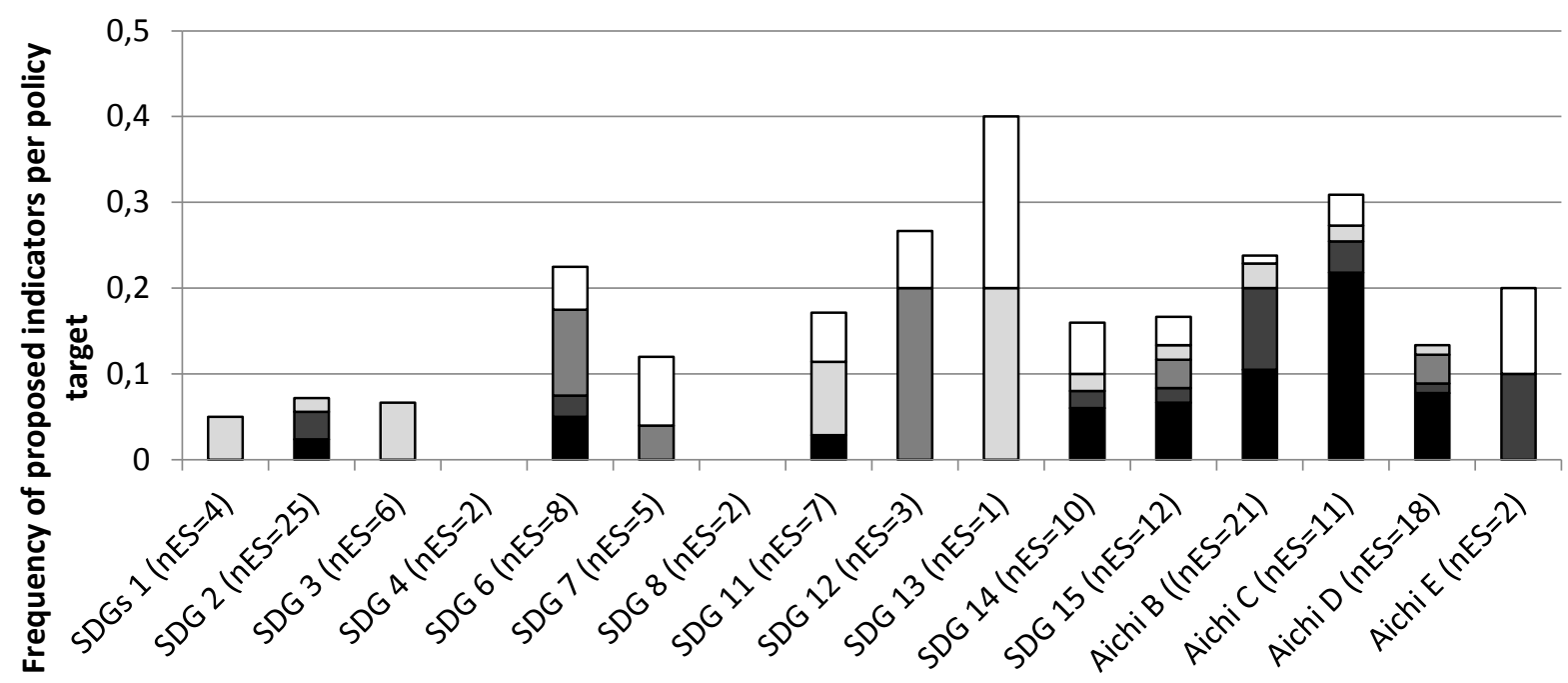

- Potential supply (nSDGS=13; nAichi = 30) पSupply (nSDGs=7; nAichi =14))

口Use (nSDGs=10; nAichi=3)

$\square$ Demand (nSDG =11;nAichi=5)

$\square$ Interest (nSDG = 13; nAichi=4)

Figure 3. Relative importance of each of the ecosystem services variables (Potential supply, Supply, The number of proposed and used indicators for the reporting on the progress of the sustainability goal in policy documents per ecosystem service variable. (B) Relative frequencies (0-1) at which information from variables are represented by indicators per policy target. Frequency values are standardized for the total number of services linked to individual policy target (nES) and the legend indicates nSDG and nAichi for the total number of proposed indicators for each ES variable per policy programme respectively. Policy targets which did not mention ecosystem services were not included in the figure.

Despite the identified value of information on ecosystem services as presented in section 3.1, it seems that entire ecosystem service flows (from Potential supply to Interest) are poorly captured by the proposed and (potentially) used indicators. The information recommended for Aichi Targets shows a strong bias on the supply side of ecosystem services flow (i.e. Potential supply and Supply), whereas this seems more balanced for SDGs. However, the overall information demanded is very low, given the number of services that are relevant for the policies (Fig. 3). Variables linked to social behaviour and ecosystem services consumption (i.e. Demand and Use) and Governance (i.e. Interest) are much less represented in Aichi targets and this bias is enforced when looking at the actually used indicators. As the SDGs reporting is based on information from national statistical bureaus, we can wonder whether their data will demonstrate a similar bias or not, as the used data sources can be of a different nature (e.g. some indicators may come from national censors). Results from section 3.3 make it clear that if SDGs reports rely only on national ecosystem reports for their information, it will likely demonstrate the same bias as found in the Aichi Target reports. To obtain more balanced information for the SDGS, national statistical bureaus would be ideally placed to add complementary social and economic data on other variables. 


\subsection{Ecosystem service information in national assessments}

313 The national ecosystem assessments analysis demonstrates the availability of a significant amount of information on ecosystem services flows at national level (Appendix A, Tab. A.4). It has to be noted that as the analysed national ecosystem assessments under represent developing countries and nonEuropean countries, the available information at a global level might be significantly lower. However, some national reports may not have been detected or included in our review, for instance because we did not find them on the internet or because they were not written in any of the languages mastered by the authors.

The available knowledge in the selected ecosystem assessments on ecosystem services flows shows, however, a considerable bias towards Supply information on provisioning services and Potential supply information for regulating services. Cultural ecosystem services as well as Use, Demand and Interest variables are not well covered in national assessments. In addition, only for some ecosystem services (e.g., Timber, Erosion Regulation, Recreation) information is available for all relevant ecosystem services variables (Fig. A.2).

In total, we identified 277 ecosystem services indicators in the ten selected ecosystem services assessments (Tab. A.2). Within these 277 indicators, most provide information on provisioning services (126, 45\%), whereas 121 indicators provide information on regulating services (44\%). The remaining 30 indicators (11\%) provide information on cultural services. Based on the network analysis, we can clearly see that indicators used for provisioning services mostly represent information on the Supply variable, whereas indicators used for regulating services mostly represent the Potential supply variable (Fig. 4).

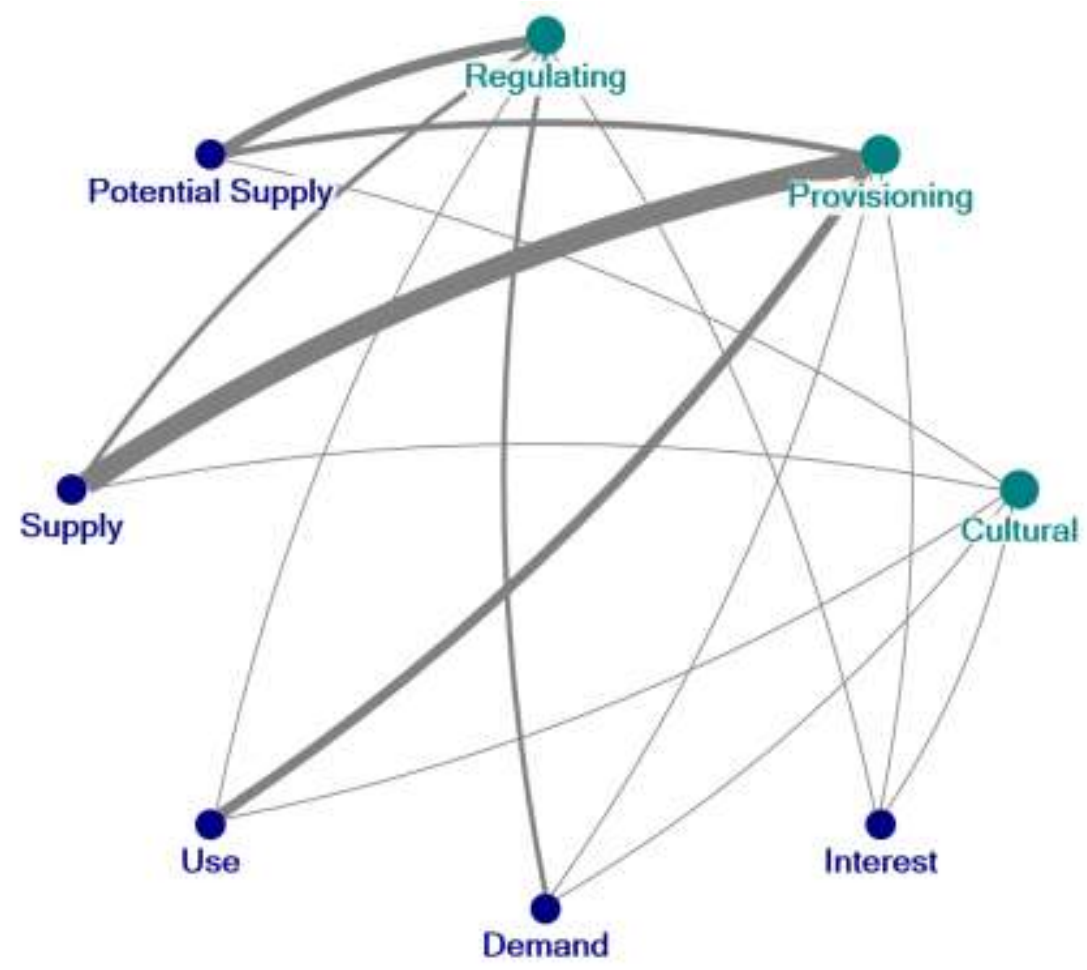


Figure 4. Relative representation of the indicators used in analysed National Ecosystem Assessments, according to ecosystem services category (provisioning, regulating or cultural services) and the ecosystem service variables (Potential supply, Supply, Use, Demand or Interest). The line width indicates the frequency at which indicators of a certain ecosystem service category were used to monitor any of the components of the ecosystem services flow. The size of the nodes is proportional to the number of ties that a node has.

Among the 277 indicators, 39 did not provide a measure of service flow, but rather of the pressure (e.g. amount of ammonia emission) or of the status quo (e.g. current air quality). None of these measures provide information on the actual ecosystem service flow; they rather reflect the response to a pressure. The status quo can be considered to result from the interplay between exerted pressure and triggered ecosystem services flow. Among the 39 indicators, 38 were used to quantify regulating services, leaving a total number of 83 indicators to quantify variables of regulating ecosystem services flows.

The 238 indicators of ecosystem service flows are almost equally divided between direct and indirect indicators, namely 124 versus 114, respectively (Tab. A.2). The distribution of the indicators within the different ecosystem service categories differs. Among the different variables, Interest is least represented by the different indicators. The pattern is most pronounced for provisioning services, where there is relatively little information available on Demand and Interest (Fig. 4). For regulating services, most information seems available on the Potential supply side of the ecosystem services flow (Fig. 4). The cultural ecosystem services category has the lowest number of indicators used for monitoring the ecosystem service flow (Tab. A.2). Regardless of general patterns, indicators are available only for very few services, for all five variables (Fig. A.2). For the top $25 \%$ services most frequently mentioned in the policies, there is a similar bias towards indicators on Supply (Tab. A.3), mainly stemming from the provisioning services crop and livestock (Tab. A.4), whereas no indicators were included for the ecosystem service Natural heritage and natural diversity.

As already acknowledged by IPBES, capacity building is needed to increase the number of readily available indicators for ecosystems services at national and global levels. The capacity to monitor spatially-explicit dynamics of ecosystem services, including multiple variables of the ecosystem services flow simultaneously, could benefit from the application of process-oriented models (e.g. Bagstad et al., 2013; Guerra et al., 2016), the use of remote sensing for specific variables (e.g. Cord et al., 2015), or by aligning with censor social and economic data (e.g. Hermans-Neumann et al., 2016).

\subsection{Recommendations for improvement towards the future}

The biased information on ecosystem service flows hampers an evaluation of progress on sustainable development. If policy reports are not able to identify whether trends in supply, consumption and demand of ecosystem services align, it will be difficult to identify if no one is left behind (Geijzendorffer et al., 2015). Apart from the results of the structured analysis, three other issues emerged from the review, which we want to mention here to raise awareness and stimulate inclusion of these issues in further scientific studies.

373 First, trade-offs play a crucial role in the interpretation of the sustainability of developments related to 374 human well-being (Liu et al., 2015; Wu, 2013) and often include regulating services (Lee and Lautenbach, 
2016). Interestingly, in the case of the SDGs, where the objective of sustainable development is a key concept, no indicators are proposed to monitor whether the impacts of progress on some objectives (e.g. industry development mentioned in Target 16) might negatively affect progress towards another objective (e.g. water availability and water quality mentioned in Target 6). Without monitoring of tradeoffs between objectives and underlying ecosystem services, it will be difficult to determine whether any progress made can be considered sustainable for improving human well-being (Costanza et al., 2016; Nilsson et al., 2016). Reporting on global sustainability policies would greatly benefit from the development and standardisation of methods to detect trends in trade-offs between ecosystem services, and between ecosystem services and other pressures. The ongoing IPBES regional and global assessments could offer excellent opportunities to develop comprehensive narratives that include the interactions between multiple ecosystem services and between them and drivers of change. Global working groups on ecosystem services from GEO BON ${ }^{2}$ and the Ecosystem Services Partnership ${ }^{3}$ can render ecosystem services data and variables usable in a wide set of monitoring and reporting contexts by developing frameworks connecting data to indicators and monitoring schemes.

Second, the applied framework of variables of ecosystem service flows did not allow for an evaluation of the most relevant spatial and temporal scales, or for indicators' units. Most ecosystem services are spatially explicit and show spatial and temporal heterogeneity that requires information on both ecological and social aspects of ecosystem services flows (e.g. Guerra et al., 2016, 2014). To monitor progress towards the Aichi Targets, the tendency to date has been to develop indicators and variables that could be quantified at global level, with the framework of Essential Biodiversity Variables being a leading concept (O'Connor et al., 2015; Pereira et al., 2013; Pettorelli et al., 2016). Although indicators with global coverage can be very effective in communicating and convincing the audience on the existence of specific trends (e.g. the Living Planet Index ${ }^{4}$ ), they are not likely to provide sufficient information to inform management or policy decisions, at local or national scales. For the SDGs, which are at a much earlier stage of development than the Aichi Targets, data will be provided at national level by national statistical bureaus (ICSU, ISSC, 2015), which may better suit national decision makers deciding on implementation of interventions. The current approach of reporting on SDGs progress at national level may also allow easier integration of information on ecosystem services available from national assessments. Although the number of available national ecosystem assessments is still rising, developing countries are currently underrepresented. Developing national assessments in these countries is therefore an important for the credible reporting on Aichi targets and SDGs.

Third, national ecosystem assessments would ideally provide information at the spatio-temporal scale and unit most relevant for the ecosystem services at hand (Costanza, 2008; Geijzendorffer and Roche, 2014). This would allow for the identification of people who do not have enough access to particular ecosystem services (e.g. gender related, income related) at a sub-national level. The assessment of progress in human well-being for different social actors within the same country, requires alternative units of measurement than national averages for the whole population in order to appraise equity aspects (Daw et al., 2011; Geijzendorffer et al., 2015). Further, although the setting of the SDGs was done by national governments, achieving sustainable development requires the engagement of multiple

${ }^{2}$ http://geobon.org/working-groups/, last consulted 22th of April 2017

${ }^{3}$ http://es-partnership.org/community/workings-groups/, last consulted 22th of April 2017

${ }^{4}$ www.livingplanetindex.org/home/index, last consulted 22th of April 2017 
social actors operating at local level. Some of these local actors (e.g. rural or indigenous communities, low-income neighbourhoods, migrants or women) play a relevant role in achieving the SDGs, because they are more vulnerable to the impact of unequal access to and distribution of ecosystem services. Although some of the indicators and objectives of SDGs mention particular actor groups (e.g. women), the representation of vulnerable groups will require special attention throughout the different targets and ecosystem services.

\section{Conclusion}

This study demonstrates that information from all ecosystem services categories is relevant for the monitoring of the Aichi Targets and the SDGs. It identifies a bias in the information demand as well as in the information available from indicators at national level towards supply related aspects of ecosystem services flows, whereas information on social behaviour, use, demand and governance implementation is much less developed.

The National statistical bureaus currently in charge of providing the data for reporting on the SDGs could be well placed to address this bias, by integrating ecological and socio-economic data. In addition, IPBES could potentially address gaps between national and global scales, as well as improve coverage of ecosystem services flows. As its first assessments of biodiversity and ecosystem services are ongoing, IPBES is still adapting its concepts. To live up to its potential role, IPBES needs to continue to adapt concepts based on scientific conceptual arguments and not based on current day practical constraints, such as a lack of data, or political sensitivities. This manuscript demonstrates the importance of data and indicators for global sustainability policies and which biases we need to start readdressing, now.

\section{Acknowledgements}

We thank the two anonymous reviewers for their suggestions, which have led to an improved final version of the manuscript. This work was partly supported by 7th Framework Programmes funded by the European Union the EU BON (Contract No. 308454) and the OPERAs project (Contract No.308393). It contributes to the Labex OT-Med (no. ANR-11-LABX-0061) funded by the French Government through the $A^{*}$ MIDEX project (no. ANR-11-IDEX-0001-02). This study contributes to the work done within the GEO BON working group on Ecosystem Services and the Mediterranean Ecosystem Services working group of the Ecosystem Services Partnership.

\section{References}

Bagstad, K.J., Johnson, G.W., Voigt, B., Villa, F., 2013. Spatial dynamics of ecosystem service flows: A comprehensive approach to quantifying actual services. Ecosyst. Serv. 4, 117-125. doi:10.1016/j.ecoser.2012.07.012

Balvanera, P., Pfisterer, A.B., Buchmann, N., He, J.-S., Nakashizuka, T., Raffaelli, D., Schmid, B., 2006. Quantifying the evidence for biodiversity effects on ecosystem functioning and services: Biodiversity and ecosystem functioning/services. Ecol. Lett. 9, 1146-1156. doi:10.1111/j.14610248.2006.00963.x 
Bastian, O., Syrbe, R.-U., Rosenberg, M., Rahe, D., Grunewald, K., 2013. The five pillar EPPS framework for quantifying, mapping and managing ecosystem services. Ecosyst. Serv. 4, 15-24. doi:10.1016/j.ecoser.2013.04.003

Bastian, M., Heymann, S., Jacomy, M., 2009. Gephi: an open source software for exploring and manipulating networks. 3rd International AAAI Conference on Weblogs and Social Media, San José, California.

Bennett, E.M., Cramer, W., Begossi, A., Cundill, G., Díaz, S., Egoh, B.N., Geijzendorffer, I.R., Krug, C.B., Lavorel, S., Lazos, E., Lebel, L., Martín-López, B., Meyfroidt, P., Mooney, H.A., Nel, J.L., Pascual, U., Payet, K., Harguindeguy, N.P., Peterson, G.D., Prieur-Richard, A.-H., Reyers, B., Roebeling, P., Seppelt, R., Solan, M., Tschakert, P., Tscharntke, T., Turner, B., Verburg, P.H., Viglizzo, E.F., White, P.C., Woodward, G., 2015. Linking biodiversity, ecosystem services, and human well-being: three challenges for designing research for sustainability. Curr. Opin. Environ. Sustain. 14, 76-85. doi:10.1016/j.cosust.2015.03.007

Böhnke-Henrichs, A., Baulcomb, C., Koss, R., Hussain, S. S., de Groot, R. S., 2013. Typology and indicators of ecosystem services for marine spatial planning and management. Journal of Env. Man., 130, 135-145.

Burkhard, B., Kroll, F., Nedkov, S., Müller, F., 2012. Mapping ecosystem service supply, demand and budgets. Ecol. Indic. 21, 17-29. doi:10.1016/j.ecolind.2011.06.019

CBD, 2015. Report of the ad hoc technical expert group on indicators for the strategic plan for biodiversity 2011-2020. Document UNEP/CBD/ID/AHTEG/2015/1/3 UNEP/CBD/SBSTTA/19/INF/5.

CBD, 2014. Global Biodiversity Outlook 4. CBD, Montréal, Canada.

$\mathrm{CBD}$, 2013. Decision document UNEP/CBD/COP/DEC/X/2; Quick guides to the Aichi Biodiversity Targets, version 2.

Cord, A.F., Seppelt, R., Turner, W., 2015. Monitor ecosystem services from space. Nature 525, 33-33.

Costanza, R., 2008. Ecosystem services: Multiple classification systems are needed. Biol. Conserv. 141, 350-352. doi:10.1016/j.biocon.2007.12.020

Costanza, R., Fioramonti, L., Kubiszewski, I., 2016. The UN Sustainable Development Goals and the dynamics of well-being. Front. Ecol. Environ. 14, 59-59. doi:10.1002/fee.1231

Crossman, N.D., Burkhard, B., Nedkov, S., Willemen, L., Petz, K., Palomo, I., Drakou, E.G., Martín-Lopez, B., McPhearson, T., Boyanova, K., Alkemade, R., Egoh, B., Dunbar, M.B., Maes, J., 2013. A blueprint for mapping and modelling ecosystem services. Ecosyst. Serv. 4, 4-14. doi:10.1016/j.ecoser.2013.02.001

Daw, T., Brown, K., Rosendo, S., Pomeroy, R., 2011. Applying the ecosystem services concept to poverty alleviation: the need to disaggregate human well-being. Environ. Conserv. 38, 370-379. doi:10.1017/S0376892911000506

de Groot, R.S., Wilson, M.A., Boumans, R.M.., 2002. A typology for the classification, description and valuation of ecosystem functions, goods and services. Ecol. Econ. 41, 393-408. doi:10.1016/S0921-8009(02)00089-7

Dymond, J., 2013. Ecosystem services in New Zealand. Landcare Research New Zealand. Manaaki Whenua Press, c2013, Lincoln, New Zealand.

Geijzendorffer, I.R., Martín-López, B., Roche, P.K., 2015. Improving the identification of mismatches in ecosystem services assessments. Ecol. Indic. 52, 320-331. doi:10.1016/j.ecolind.2014.12.016

Geijzendorffer, I.R., Roche, P.K., 2014. The relevant scales of ecosystem services demand. Ecosyst. Serv. 10, 49-51. doi:10.1016/j.ecoser.2014.09.002

Griggs, D., Stafford-Smith, M., Gaffney, O., Rockström, J., Öhman, M.C., Shyamsundar, P., Steffen, W., Glaser, G., Kanie, N., Noble, I., 2013. Policy: Sustainable development goals for people and planet. Nature 495, 305-307. doi:10.1038/495305a 
500

501

502

503

504

505

506

507

508

509

510

511

512

513

514

515

516

517

518

519

520

521

522

523

524

525

526

527

528

529

530

531

532

533

534

535

536

537

538

539

540

541

542

543

544

545

546

547

Guerra, C.A., Maes, J., Geijzendorffer, I., Metzger, M.J., 2016. An assessment of soil erosion prevention by vegetation in Mediterranean Europe: Current trends of ecosystem service provision. Ecol. Indic. 60, 213-222. doi:10.1016/j.ecolind.2015.06.043

Guerra, C.A., Pinto-Correia, T., Metzger, M.J., 2014. Mapping Soil Erosion Prevention Using an Ecosystem Service Modeling Framework for Integrated Land Management and Policy. Ecosystems 17, 878889. doi:10.1007/s10021-014-9766-4

Hák, T., Janoušková, S., Moldan, B., 2016b. Sustainable Development Goals: A need for relevant indicators. Ecol. Indic. 60, 565-573. doi:10.1016/j.ecolind.2015.08.003

Harrington, R., Anton, C., Dawson, T.P., de Bello, F., Feld, C.K., Haslett, J.R., Kluvánkova-Oravská, T., Kontogianni, A., Lavorel, S., Luck, G.W., Rounsevell, M.D.A., Samways, M.J., Settele, J., Skourtos, M., Spangenberg, J.H., Vandewalle, M., Zobel, M., Harrison, P.A., 2010. Ecosystem services and biodiversity conservation: concepts and a glossary. Biodivers. Conserv. 19, 2773-2790. doi:10.1007/s10531-010-9834-9

Hernández-Morcillo, M., Plieninger, T., Bieling, C., 2013. n empirical review of cultural ecosystem service indicators." Ecol. Indic. 29, 434-444.

Hicks, C.C., Levine, A., Agrawal, A., Basurto, X., Breslow, S.J., Carothers, C., Charnley, S., Coulthard, S., Dolsak, N., Donatuto, J., Garcia-Quijano, C., Mascia, M.B., Norman, K., Poe, M.R., Satterfield, T., St. Martin, K., Levin, P.S., 2016. Engage key social concepts for sustainability. Science 352, 38-40. doi:10.1126/science.aad4977

ICSU, ISSC, 2015. Review of the Sustainable Development Goals: The Science Perspective. International Council for Science (ICSU), paris.

Kandziora, M., Burkhard, B., Müller, F., 2013. Interactions of ecosystem properties, ecosystem integrity and ecosystem service indicators - A theoretical matrix exercise. Ecol. Indic. 28, 54-78. doi:10.1016/j.ecolind.2012.09.006

Le Blanc, D., 2015. Towards Integration at Last? The Sustainable Development Goals as a Network of Targets: The sustainable development goals as a network of targets. Sustain. Dev. 23, 176-187. doi:10.1002/sd.1582

Lee, H., Lautenbach, S., 2016. A quantitative review of relationships between ecosystem services. Ecol. Indic. 66, 340-351. doi:10.1016/j.ecolind.2016.02.004

Liu, J., Mooney, H., Hull, V., Davis, S.J., Gaskell, J., Hertel, T., Lubchenco, J., Seto, K.C., Gleick, P., Kremen, C., Li, S., 2015. Systems integration for global sustainability. Science 347, 1258832-1258832. doi:10.1126/science.1258832

Lu, Y., Nakicenovic, N., Visbeck, M., Stevance, A.-S., 2015. Policy: Five priorities for the UN Sustainable Development Goals. Nature 520, 432-433. doi:10.1038/520432a

Maes, J., Fabrega, N., Zulian, G., Barbosa, A., Vizvaino, P., Ivits, E., Polca, C., Vandecasteele, I., Marí Rivero, I., Guerra, C., Perpiña Castillo, C., Vallecillo, S., Baranzelli, C., Barranco, R., Bastita e Silva, F., Jacobs-Crisoni, C., Trombetti, M., Lavelle, C., 2015. Mapping and Assessment of Ecosystems and their Services: Trends in ecosystems and ecosystem services in the European Union between 2000 and 2010., JRC Science and Policy report. ed. Publications Office of the European Union, Luxembourg.

Maes, J., Liquete, C., Teller, A., Erhard, M., Paracchini, M.L., Barredo, J.I., Grizzetti, B., Cardoso, A., Somma, F., Petersen, J.-E., Meiner, A., Gelabert, E.R., Zal, N., Kristensen, P., Bastrup-Birk, A., Biala, K., Piroddi, C., Egoh, B., Degeorges, P., Fiorina, C., Santos-Martín, F., Naruševičius, V., Verboven, J., Pereira, H.M., Bengtsson, J., Gocheva, K., Marta-Pedroso, C., Snäll, T., Estreguil, C., San-Miguel-Ayanz, J., Pérez-Soba, M., Grêt-Regamey, A., Lillebø, A.I., Malak, D.A., Condé, S., Moen, J., Czúcz, B., Drakou, E.G., Zulian, G., Lavalle, C., 2016. An indicator framework for assessing ecosystem services in support of the EU Biodiversity Strategy to 2020. Ecosyst. Serv. 17, 14-23. doi:10.1016/j.ecoser.2015.10.023 
Martín-López, B., Gómez-Baggethun, E., García-Llorente, M., Montes, C., 2014. Trade-offs across valuedomains in ecosystem services assessment. Ecol. Indic. 37, 220-228. doi:10.1016/j.ecolind.2013.03.003

Milcu, A., Hanspach, J., Abson, D., Fischer, J., 2013. Cultural ecosystem services: a literature review and prospects for future research. Ecology and Society, 18, 3.

Nilsson, M., Griggs, D., Visbeck, M., 2016. Policy: Map the interactions between Sustainable Development Goals. Nature 534, 320-322. doi:10.1038/534320a

O'Connor, B., Secades, C., Penner, J., Sonnenschein, R., Skidmore, A., Burgess, N.D., Hutton, J.M., 2015. Earth observation as a tool for tracking progress towards the Aichi Biodiversity Targets. Remote Sens. Ecol. Conserv. 1, 19-28. doi:10.1002/rse2.4

Pereira, H.M., Ferrier, S., Walters, M., Geller, G.N., Jongman, R.H.G., Scholes, R.J., Bruford, M.W., Brummitt, N., Butchart, S.H.M., Cardoso, A.C., Coops, N.C., Dulloo, E., Faith, D.P., Freyhof, J., Gregory, R.D., Heip, C., Hoft, R., Hurtt, G., Jetz, W., Karp, D.S., McGeoch, M.A., Obura, D., Onoda, Y., Pettorelli, N., Reyers, B., Sayre, R., Scharlemann, J.P.W., Stuart, S.N., Turak, E., Walpole, M., Wegmann, M., 2013. Essential Biodiversity Variables. Science 339, 277-278. doi:10.1126/science.1229931

Pettorelli, N., Wegmann, M., Skidmore, A., Mücher, S., Dawson, T.P., Fernandez, M., Lucas, R., Schaepman, M.E., Wang, T., O'Connor, B., Jongman, R.H.G., Kempeneers, P., Sonnenschein, R., Leidner, A.K., Böhm, M., He, K.S., Nagendra, H., Dubois, G., Fatoyinbo, T., Hansen, M.C., Paganini, M., de Klerk, H.M., Asner, G.P., Kerr, J.T., Estes, A.B., Schmeller, D.S., Heiden, U., Rocchini, D., Pereira, H.M., Turak, E., Fernandez, N., Lausch, A., Cho, M.A., Alcaraz-Segura, D., McGeoch, M.A., Turner, W., Mueller, A., St-Louis, V., Penner, J., Vihervaara, P., Belward, A., Reyers, B., Geller, G.N., 2016. Framing the concept of satellite remote sensing essential biodiversity variables: challenges and future directions. Remote Sens. Ecol. Conserv. n/a-n/a. doi:10.1002/rse2.15

Reyers, B., Nel, J., O’Farrell, P., Selomane, O., Smith, J., Yapi, T., 2014. Assessing ecosystem service change \& its impacts on human wellbeing. A national pilot of indicator approaches and data., CSIR Report CSIR/NRE/ECOS/IR/2014/0016/B. ed.

Santos-Martín, F., Martín-López, B., García-Llorente, M., Aguado, M., Benayas, J., Montes, C., 2013. Unraveling the Relationships between Ecosystems and Human Wellbeing in Spain. PLoS ONE 8, e73249. doi:10.1371/journal.pone.0073249

Schröter, D., Cramer, W., Leemans, R., Prentice, I.C., Araújo, M.B., Arnell, N.W., Bondeau, A., Bugmann, H., Carter, T.R., Garcia, C.A., de la Vega-Leinert, A.C., Erhard, M., Ewert, F., Glendining, M., House, J.I., Kankaanpää, S., Klein, R.J.T., Lavorel, S., Lindner, M., Metzger, M.J., Meyer, J., Mitchell, T.D., Reginster, I., Rounsevell, M., Sabaté, S., Sitch, S., Smith, B., Smith, J., Smith, P., Sykes, M.T., Thonicke, K., Thuiller, W., Tuck, G., Zaehle, S., Zierl, B. 2005 Ecosystem Service Supply and Vulnerability to Global Change in Europe. Science 310(25.11.2005):1333-1337, doi: 10.1126/science.1115233

Schröter, M., Barton, D.N., Remme, R.P., Hein, L., 2014. Accounting for capacity and flow of ecosystem services: A conceptual model and a case study for Telemark, Norway. Ecol. Indic. 36, 539-551. doi:10.1016/j.ecolind.2013.09.018

Stevens, M., 2014. Natuurrapport - Toestand en trend van ecosystemen en ecosysteemdiensten in Vlaanderen, Technisch rapport. Mededelingen van het Instituut voor Natuur-en Bosonderzoek, INBO.M.2014.1988582. ed. Brussel.

Sunderlin, W.D., Angelsen, A., Belcher, B., Burgers, P., Nasi, R., Santoso, L., Wunder, S., 2005. Livelihoods, forests, and conservation in developing countries: An Overview. World Dev. 33, 1383-1402. doi:10.1016/j.worlddev.2004.10.004

UK National Ecosystem Assessment, 2011. The UK National Ecosystem Assessment: Synthesis of the Key Findings. 
596 United Nations, 2015a. Transforming our world: the 2030 Agenda for Sustainable Development Document A/RES/70/1, Resolution Adopted by the General Assembly on 25 September 2015.

598 United Nations, 2015b. Report of the Inter-Agency and Expert Group on Sustainable Development Goal 599 Indicators, Decision document E/CN.3/2016/2.

van Oudenhoven, A.P.E., Petz, K., Alkemade, R., Hein, L., de Groot, R.S., 2012. Framework for systematic indicator selection to assess effects of land management on ecosystem services. Ecol. Indic. 21, 110-122. doi:10.1016/j.ecolind.2012.01.012

Villamagna, A.M., Angermeier, P.L., Bennett, E.M., 2013. Capacity, pressure, demand, and flow: A conceptual framework for analyzing ecosystem service provision and delivery. Ecol. Complex. 15, 114-121. doi:10.1016/j.ecocom.2013.07.004

Willemen, L., Crossman, N., Egoh, B., Kalaba, F., Mbilinyi, B., Groot, R. de, 2015. Mapping and Valuing Ecosystem Services in South Africa, Tanzania and Zambia. consultancy report CCD/15/GM03.

Wood, S.L., DeClerck, F., 2015. Ecosystems and human well-being in the Sustainable Development Goals. Front. Ecol. Environ. 13, 123-123. doi:10.1890/1540-9295-13.3.123

$\mathrm{Wu}$, J., 2013. Landscape sustainability science: ecosystem services and human well-being in changing landscapes. Landsc. Ecol. 28, 999-1023. doi:10.1007/s10980-013-9894-9 
Appendix A: The frequency at which ecosystem services are mentioned per target, in the policy documents.

Table A.1. Overall ranking of the frequency that ecosystem services were mentioned across both the SDGs and the Aichi Targets. The top $25 \%$ most frequently mentioned ecosystem services are highlighted in bold. Ecosystem services categories are Provisioning (P), Regulating (R) and Cultural (C).

\begin{tabular}{|c|c|c|c|c|}
\hline $\begin{array}{l}\text { Ecosystem } \\
\text { service category }\end{array}$ & Ecosystem services & $\begin{array}{c}\text { SDGs } \\
\text { Ranking }\end{array}$ & $\begin{array}{c}\text { Aichi Targets } \\
\text { Ranking }\end{array}$ & $\begin{array}{c}\text { Combined } \\
\text { ranking }\end{array}$ \\
\hline $\mathrm{C}$ & Natural heritage \& natural diversity & 1 & 1 & 1 \\
\hline $\mathbf{P}$ & Capture fisheries & 2 & 8 & 2 \\
\hline $\mathbf{P}$ & Aquaculture & 6 & 8 & 3.5 \\
\hline $\mathbf{R}$ & Water purification & 6 & 8 & 3.5 \\
\hline $\mathbf{P}$ & Crops & 9,5 & 8 & 6 \\
\hline $\mathbf{P}$ & Livestock & 9,5 & 8 & 6 \\
\hline $\mathbf{C}$ & Cultural heritage \& cultural diversity & 9,5 & 8 & 6 \\
\hline $\mathrm{R}$ & Erosion regulation & 12,5 & 8 & 8,5 \\
\hline $\mathrm{R}$ & Regulation of waste & 3,5 & 17,5 & 8,5 \\
\hline $\mathrm{R}$ & Water flow regulation & 6 & 17,5 & 10 \\
\hline $\mathrm{P}$ & Wild foods & 17 & 8 & 12 \\
\hline$P$ & Freshwater & 17 & 8 & 12 \\
\hline C & Knowledge systems & 17 & 8 & 12 \\
\hline $\mathrm{R}$ & Natural hazard protection & 3,5 & 23,5 & 14 \\
\hline $\mathrm{P}$ & Timber & 25,5 & 8 & 16 \\
\hline $\mathrm{P}$ & Biochemicals/medicine & 25,5 & 8 & 16 \\
\hline $\mathrm{R}$ & Nutrient regulation & 25,5 & 8 & 16 \\
\hline $\mathrm{R}$ & Pest and disease control & 17 & 17,5 & 18 \\
\hline $\mathrm{R}$ & Local climate regulation & 12,5 & 23,5 & 19 \\
\hline $\mathrm{C}$ & Recreation & 9,5 & 28 & 20 \\
\hline $\mathrm{R}$ & Pollination & 21 & 17,5 & 21 \\
\hline $\mathrm{P}$ & Energy (biomass) & 17 & 23,5 & 22,5 \\
\hline $\mathrm{P}$ & Wood for fuel & 17 & 23,5 & 22,5 \\
\hline $\mathrm{P}$ & Fibre & 25,5 & 17,5 & 24 \\
\hline $\mathrm{R}$ & Global climate regulation & 25,5 & 17,5 & 25 \\
\hline $\mathrm{R}$ & Air quality regulation & 17 & 28 & 26 \\
\hline $\mathrm{P}$ & Fodder & 25,5 & 23,5 & 27,5 \\
\hline $\mathrm{C}$ & Religious and spiritual experiences & 25,5 & 23,5 & 27,5 \\
\hline $\mathrm{C}$ & Landscape aesthetics & 25,5 & 28 & 29 \\
\hline
\end{tabular}




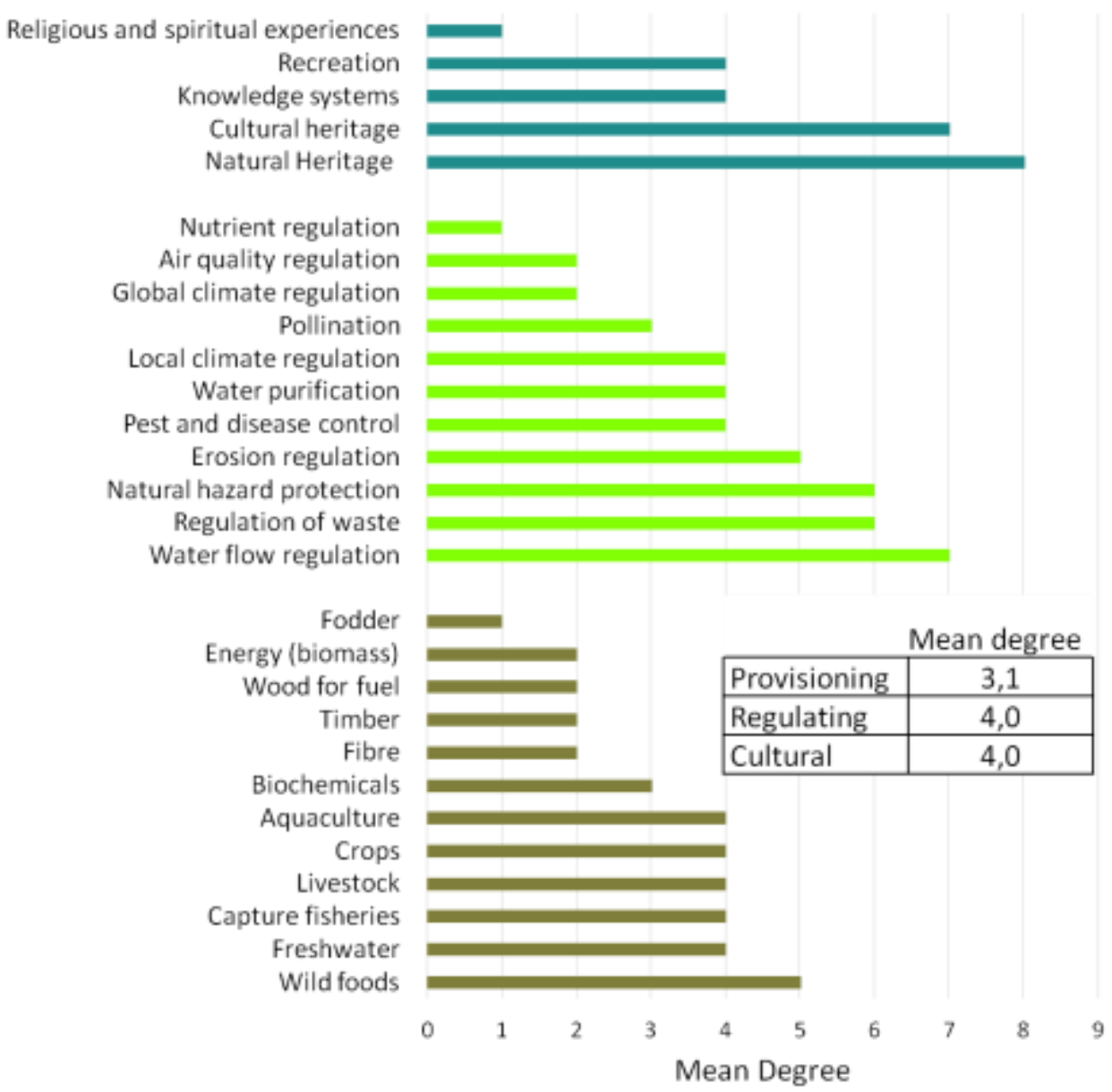

Figure A.1: Degree (the number of connections) per ecosystem service across both policy documents 
Assessment of the representation of the indicators used in the ten selected national assessments of the ecosystem services, ecosystem service categories and ecosystem service variables.

Table A.2. Number of indicators identified from national ecosystem assessments, presented per ecosystem service category (provisioning, regulating or cultural services), ecosystem service variable (Potential Supply, Supply, Use, Demand or Interest) or indicator type (direct or indirect). For regulating services, 39 additional indicators describing pressures and states were identified.

\begin{tabular}{l|cc|cccccc|} 
& Direct & Indirect & $\begin{array}{l}\text { Potential } \\
\text { Supply }\end{array}$ & Supply & Use & Demand & Interest \\
\hline Total & 124 & 114 & 59 & 89 & 46 & 31 & 13 \\
\hline Provisioning & 82 & 43 & 22 & 61 & 31 & 8 & 3 \\
Regulating & 26 & 57 & 34 & 19 & 5 & 18 & 7 \\
Cultural & 16 & 14 & 3 & 9 & 10 & 5 & 3 \\
\hline Potential Supply & 19 & 40 & & & & & \\
Supply & 45 & 44 & & & & & \\
Use & 40 & 6 & & & & & \\
Demand & 17 & 14 & & & & & \\
Interest & 3 & 10 & & & & & \\
\cline { 1 - 4 } & & & & & & & & \\
\end{tabular}

Table A.3. Number of indicators identified from ecosystem services assessments for the top $25 \%$ of ecosystem services recommended by the reviewed policies, presented per ecosystem service variable (Potential Supply, Supply, Use, Demand or Interest) or indicator type (direct or indirect).

Natural Heritage \& natural diversity Capture fisheries

Aquaculture

Water purification

Crops

Cultural heritage \& cultural diversity Livestock

Total number of Direct or Indirect indicators per Variable type Total number of indicators per Variable type

\begin{tabular}{|c|c|c|c|c|c|c|c|c|c|}
\hline \multicolumn{2}{|c|}{ Potential supply } & \multicolumn{2}{|c|}{ Supply } & \multicolumn{2}{|c|}{ Use } & \multicolumn{2}{|c|}{ Demand } & \multicolumn{2}{|c|}{ Interest } \\
\hline 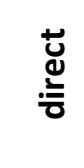 & 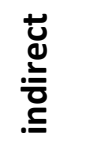 & $\begin{array}{l}\stackrel{ّ}{\mathrm{U}} \\
\frac{.0}{\partial}\end{array}$ & 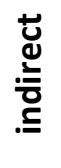 & 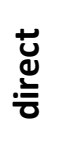 & 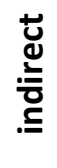 & $\begin{array}{l}\stackrel{ّ}{d} \\
\frac{.0}{0}\end{array}$ & 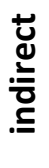 & 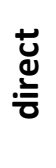 & 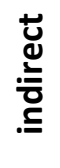 \\
\hline- & - & - & - & - & - & - & - & - & - \\
\hline 0 & 0 & 1 & 0 & 0 & 1 & 0 & 0 & 0 & 0 \\
\hline 0 & 0 & 2 & 0 & 0 & 0 & 0 & 0 & 0 & 0 \\
\hline 2 & 1 & 3 & 3 & 0 & 0 & 2 & 2 & 0 & 0 \\
\hline 0 & 0 & 5 & 8 & 1 & 0 & 0 & 0 & 0 & 0 \\
\hline 0 & 0 & 2 & 0 & 1 & 0 & 1 & 0 & 1 & 0 \\
\hline 2 & 0 & 1 & 4 & 5 & 0 & 0 & 0 & 0 & 0 \\
\hline 4 & 1 & 14 & 15 & 7 & 1 & 3 & 2 & 1 & 0 \\
\hline
\end{tabular}

The review of the national assessment reports showed no indicators explicitly linked to the Natural heritage and natural diversity service (Table S3). We might consider that some aspects of this service may be captured by other cultural services, such as the appreciation by tourists or knowledge systems. 
However, the interpretation of this specific service is generally considered to be very difficult. Many consider that the intrinsic value of biodiversity, although very important, cannot be considered an ecosystem service as the direct benefit for human well-being is not evident, but rather as an ecological characteristic (Balvanera et al., 2006; Kandziora et al., 2013). To include to the Natural heritage and natural diversity service in our review, we considered that only information on biodiversity aspects for which human appreciation was explicitly used as criteria, should be included in this particular ecosystem service. This means that general patterns in species abundance (e.g. Living Planet Index), habitat extent or the presence of red list of species, were considered as important variables for biodiversity, only if they supported specific ecological functions (e.g. mangrove extent for life cycle maintenance by providing nurseries for fish), but not as an indicator for the supply of the natural heritage service in general. 
Table A.4. Overview of the distribution of 277 indicators from ten selected national ecosystem assessment over the different ecosystem services and ecosystem service variables.

\begin{tabular}{|c|c|c|c|c|c|c|c|c|c|c|c|c|}
\hline \multirow[b]{3}{*}{ Ecosystem services and categories* } & \multirow[b]{3}{*}{$\begin{array}{l}\text { Total number of } \\
\text { indicators }\end{array}$} & \multicolumn{10}{|c|}{ Ecosystem service variables } & \multirow{3}{*}{$\begin{array}{c}\text { Indicators } \\
\text { on } \\
\text { pressures } \\
\text { or current } \\
\text { state }\end{array}$} \\
\hline & & \multicolumn{2}{|c|}{$\begin{array}{l}\text { Potential } \\
\text { supply }\end{array}$} & \multicolumn{2}{|c|}{ Supply } & \multicolumn{2}{|c|}{ Use } & \multicolumn{2}{|c|}{ Demand } & \multicolumn{2}{|c|}{ Interest } & \\
\hline & & 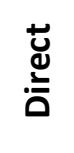 & 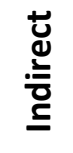 & 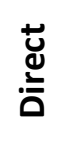 & 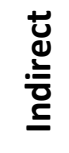 & 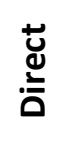 & 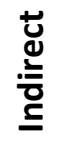 & 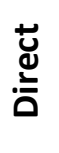 & 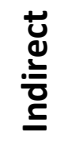 & 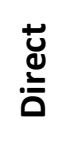 & 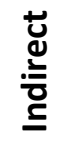 & \\
\hline Provisioning services & 125 & 11 & 11 & 35 & 26 & 28 & 3 & 8 & 0 & 0 & 3 & 1 \\
\hline Crops & 14 & 0 & 0 & 5 & 8 & 1 & 0 & 0 & 0 & 0 & 0 & 0 \\
\hline Fodder & 5 & 0 & 0 & 1 & 2 & 0 & 0 & 2 & 0 & 0 & 0 & 0 \\
\hline Products from domestic animals* & 12 & 2 & 0 & 1 & 4 & 5 & 0 & 0 & 0 & 0 & 0 & 0 \\
\hline Fish & 2 & 0 & 0 & 1 & 0 & 0 & 1 & 0 & 0 & 0 & 0 & 0 \\
\hline Aquaculture & 2 & 0 & 0 & 2 & 0 & 0 & 0 & 0 & 0 & 0 & 0 & 0 \\
\hline Fibre & 4 & 0 & 0 & 3 & 0 & 1 & 0 & 0 & 0 & 0 & 0 & 0 \\
\hline Timber & 22 & 6 & 0 & 5 & 6 & 1 & 1 & 1 & 0 & 0 & 2 & 0 \\
\hline Wild foods & 18 & 0 & 6 & 3 & 0 & 8 & 0 & 1 & 0 & 0 & 0 & 0 \\
\hline Wood fuel and biomass for energy & 22 & 1 & 1 & 8 & 4 & 4 & 1 & 2 & 0 & 0 & 1 & 0 \\
\hline Fresh water & 24 & 2 & 4 & 6 & 2 & 8 & 0 & 2 & 0 & 0 & 0 & 1 \\
\hline Regulating services & 83 & 7 & 27 & 8 & 11 & 4 & 1 & 5 & 13 & 2 & 5 & 38 \\
\hline Pollination & 5 & 0 & 3 & 0 & 1 & 0 & 0 & 0 & 1 & 0 & 0 & 1 \\
\hline Pest and disease control & 0 & 0 & 0 & 0 & 0 & 0 & 0 & 0 & 0 & 0 & 0 & 1 \\
\hline Nutrient regulation & 6 & 2 & 1 & 0 & 1 & 0 & 1 & 0 & 1 & 0 & 0 & 3 \\
\hline Air quality regulation & 5 & 1 & 1 & 0 & 1 & 1 & 0 & 1 & 0 & 0 & 0 & 4 \\
\hline Noise reduction* & 6 & 2 & 0 & 0 & 1 & 0 & 0 & 0 & 2 & 0 & 1 & 0 \\
\hline Erosion regulation & 14 & 0 & 3 & 2 & 0 & 2 & 0 & 1 & 4 & 2 & 0 & 5 \\
\hline Flood risk regulation* & 10 & 0 & 3 & 0 & 2 & 0 & 0 & 1 & 0 & 0 & 4 & 7 \\
\hline Coastal protection* & 5 & 0 & 2 & 1 & 1 & 0 & 0 & 0 & 1 & 0 & 0 & 0 \\
\hline Global climate regulation & 12 & 0 & 7 & 2 & 1 & 1 & 0 & 0 & 1 & 0 & 0 & 2 \\
\hline Water purification & 13 & 2 & 1 & 3 & 3 & 0 & 0 & 2 & 2 & 0 & 0 & 10 \\
\hline
\end{tabular}




\begin{tabular}{|c|c|c|c|c|c|c|c|c|c|c|c|c|}
\hline Water flow regulation & 7 & 0 & 6 & 0 & 0 & 0 & 0 & 0 & 1 & 0 & 0 & 1 \\
\hline Soil quality regulation* & 0 & 0 & 0 & 0 & 0 & 0 & 0 & 0 & 0 & 0 & 0 & 2 \\
\hline Lifecycle maintenance* & 0 & 0 & 0 & 0 & 0 & 0 & 0 & 0 & 0 & 0 & 0 & 2 \\
\hline Cultural services & 30 & 1 & 2 & 2 & 7 & 8 & 2 & 4 & 1 & 1 & 2 & 0 \\
\hline Recreation* & 13 & 1 & 0 & 0 & 4 & 3 & 2 & 0 & 1 & 0 & 2 & 0 \\
\hline Tourism* & 11 & 0 & 2 & 0 & 2 & 4 & 0 & 3 & 0 & 0 & 0 & 0 \\
\hline Knowledge systems and education & 1 & 0 & 0 & 0 & 1 & 0 & 0 & 0 & 0 & 0 & 0 & 0 \\
\hline Cultural heritage and cultural diversity & 5 & 0 & 0 & 2 & 0 & 1 & 0 & 1 & 0 & 1 & 0 & 0 \\
\hline \multicolumn{13}{|c|}{$\begin{array}{l}\text { * In the paper we used the ecosystem services definitions from Kandziora et al. (Kandziora et al., 2013), but based on the indicators found } \\
\text { in the selected ecosystem services assessments, we made small adjustments: 1) for livestock the definition remained the same, but we } \\
\text { changed the name for clarity in the table; } 2 \text { ) noise reduction, soil quality regulation and lifecycle maintenance were absent from } \\
\text { Kandziora et al., (Kandziora et al., 2013) and were added; 3) we split natural hazard regulation in two: flood risk regulation and coastal } \\
\text { protection; and 4) we separated recreation and tourism. }\end{array}$} \\
\hline
\end{tabular}


Cultural heritage and cultural diversity $(n=5)$

Knowledge systems $(n=1)$

Tourism $(n=11)$

Recreation $(n=13)$

Lifecycle maintenance $(n=0)$

Soil quality regulation $(n=0)$

Water flow regulation $(n=7)$

Water purification $(n=13)$

Global climate regulation ( $n=12$ )

Coastal protection $(n=5)$

Flood risk regulation $(n=10)$

Erosion regulation $(n=14)$

Noise reduction $(n=6)$

Air quality regulation $(n=5)$

Nutrient regulation $(n=6)$

Pest and disease control

Pollination $(n=5)$

Fresh water $(n=24)$

Wood fuel and biomass for energy $(n=22)$

Wild foods $(n=18)$

Timber $(n=22$

Fibre $(n=4)$

Fodder $(n=2)$

Aquaculture $(n=2)$

Fish $(n=12$

Products from animals $(n=5)$

Crop $(n=14)$

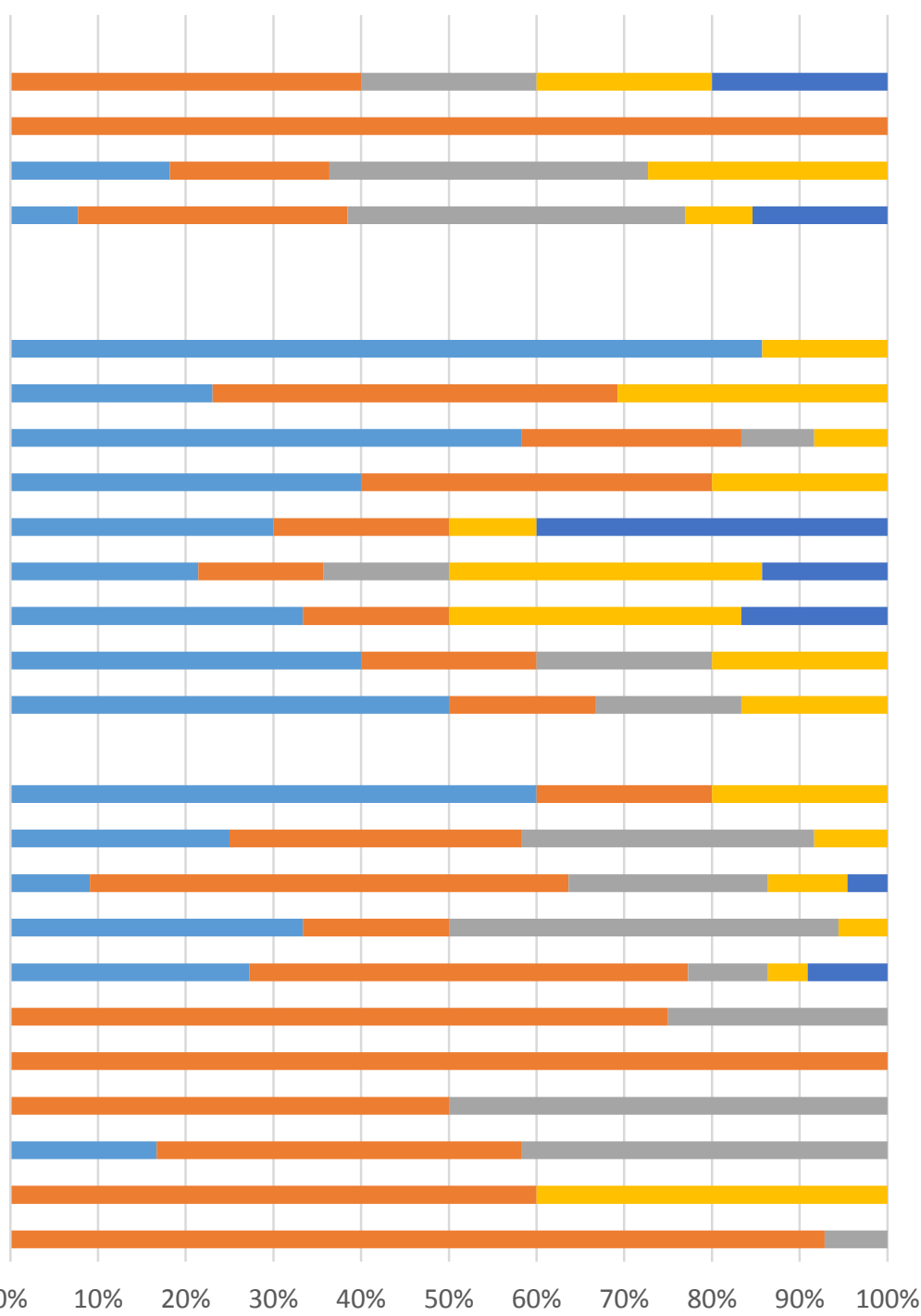

Relative distribution of used indicators per ecosystem service per ecosys variable

potential supply a supply use demand a Interest

Figure A.2. Relative distribution of indicators used in national assessments per ecosystem service per ecosystem service variable. For the services Lifecycle maintenance, soil quality regulation and Biological control, the national assessments only presented indicators describing pressures or current status quo, but not on the ecosystem service variables. 